\title{
PEMBERDAYAAN PEMILIK KIOS DI PASAR KUNCIRAN INDAH KOTA TANGERANG, PROVINSI BANTEN
}

\author{
Muhammad Tony Nawawi ${ }^{1}$, Purwanto ${ }^{2}$, Urbanus $W^{3}$. \\ ${ }^{1}$ Jurusan Manajemen, Universitas Tarumanagara, Jakarta \\ Email:tonyn@fe.untar.ac.id \\ ${ }^{2}$ Jurusan Manajemen, Universitas Tarumanagara, Jakarta \\ Email: purwanto@fe.untar.ac.id \\ ${ }^{3}$ Jurusan Manajemen, Universitas Tarumanagara, Jakarta \\ Email: urbanusw@fe.untar.ac.id.
}

\begin{abstract}
ABSTRAK
Kegiatan Pengabdian Kepada Masyarakat (PKM) ini dilakukan untuk membantu kelompok pemilik Kios di pasar kunciran indah, Pinang, Kota Tangerang, Hasil observasi kepada pemilik kios di pasar kunciran indah, dalam hal ini diwakili oleh Bapak Abdul Syukur. Dan pemilik kios ibu Ambar, teridentifikasi masalah yang menjadi prioritas adalah minimnya pembeli ke kios pasar kunciran indah. Jumlah kios yang tersedia banyak sementara yang pembeli masih sedikit, terutama untuk produk kebutuhan sehari-hari. Hal tersebut terkait dengan aspek produksi, yaitu belum adanya promosi dan yang mendorong masyarakat untuk berbelanja ke pasar kunciran indah. Pada aspek manajemen terkait dengan minat/sikap pemilik kios untuk berusaha di pasar kunciran rendah, perlu upaya untuk memberikan dorongan/memotivasi pemilik kios agar berpartisipasi dalam pemberdayaan kiosnya. Melalui kegiatan yang dilakukan oleh Tim Pengabdian Kepada Masyarakat (PKM) Universitas Tarumanagara ini, setidaknya dapat membantu mengatasi persoalan yang dihadapi mitra tersebut. Dan dapat meningkatkan motivasi usaha bagi pemilik kios, juga meningkatkan omset penjualan usaha mereka. Berdasarkan kegiatan PKM, maka hasilnya adalah terealisasinya penyusunan materi motivasi usaha, pelaksanaan sosialisasi kepada mitra usaha tentang Materi promosi berjalan dengan baik, pelaksanaan pembuatan media media promosi seperti spanduk, terealisasinya spanduk spanduk dan lainnya yang dipajang sedemikian rupa sehingga menarik perhatian konsumen yang lalu lalang di depan tempat usaha. Dengan melihat kondisi pemilik usaha dalam menjalankan usaha, terutama dalam mengkomunikasikan usaha pada konsumen.
\end{abstract}

Kata kunci: Pasar kunciran; produksi; motivasi; promosi; FDG.

\section{PENDAHULUAN}

Pasar-pasar tradisional yang berubah menjadi pasar modern yang pasti nyaman dan bersih bagi pengunjungnya. Khusunya pasar yang satu ini yaitu Pasar Kunciran lokasi di Jl. KH. Hasyim ashari, sudimara, pinang, Kota Tangerang. Pasar yang dulunya merupakan pasar tradisional yang sudah ada sejak tahun 2010 bahkan sebelum wilayah disekitar pasar berkembang seperti sekarang ini. Pasar dengan luas kurang lebih 1500 meter persegi ini menjadi pasar kunciran jaya yang menyediakan berbagai macam kebutuhan harian didalamnya. Di jual diperuntukan untuk produk basah seperti sayur-mayur, ikan, daging, dll. Di lokasi ini terdapat sekitar 100 kios dengan ukuran yang berbeda. Pasar Kunciran indah merupakan pilot project dari pembangunan 5 pasar tradisional (pasar lingkungan) yang ada di Kota Tangerang. Jika pembangunan pasar ini sukses, tentunya akan dilakukan pada pasar lainnya. "Kerjasama ini akan dijalin selama lima tahun ke depan. Namun demikian melalui observasi ke pasar kunciran, banyaknya unit kios yang dibangun tidak banyak yang buka, bahkan masih banyak kios yang kosong. Banyak pemilik kios yang tidak membuka tokonya, bahkan tidak ada usaha dari pengelola pasar yang dalam hal ini ditangani pihak swasta tidak ada upaya melakukan event atau promosi yang dapat menarik pemilik untuk membuka usaha. Pasar Lingkungan yang dibangun Perusahaan Daerah Pasar (PD Pasar) Kota Tangerang merupakan wujud kepedulian PD Pasar, terhadap keberadaan pasar agar dekat dengan masyarakat. Hal ini dibuktikan dengan dibangunnya 4 dari 5 Pasling yang sudah berjalan, antara 
lain Periuk Jaya, Manis Jaya, Jurumudi, Kunciran Indah, dan untuk Larangan Utara dalam tahap finishing.

Menurut Kepala PD Pasar Kota Tangerang, Titien Mulyati, Pasling yang dibangun tersebut merupakan upaya pihaknya dalam memberikan tempat ke para pedagang lingkungan, yang berdekatan dengan Pasling untuk menjalankan kegiatan usaha mereka. Program ini telah lebih dahulu dikoordinasikan dengan pihak kelurahan setempat, jelas Titien Mulyati. Titien pun berharap, agar pihak pengurus lingkungan baik itu RT maupun RW, yang selama ini sudah berkerjasama dengan PD Pasar Kota Tangerang harus benar - benar menjaga dan memafaatkan Pasling dengan cara menjaga kebersihan, keamanan serta ketertiban Pasling yang ada di lingkungannya, agar kondisi pasar tetap terasa nyaman bagi para pengunjungnya. Karena pasar sudah dekat dengan lingkungan tempat tinggal masyarakat, diharapkan masyarakat tidak perlu lagi jauh-jauh, sebab dilingkungan sendiri sudah disediakan pasar lingkungan, yang menyediakan kebutuhan mereka," kata Titien. Program ini juga bisa berfungsi untuk mengurangi kemacetan serta dapat menambah penghasilan masyarakat di sekitarnya," pungkasnya. Dari wawancara dengan Bapak Abdul syukur selaku pemilik kios, banyak yang tidak termotivasi membuka usaha di pasar kunciran. Padahal dari segi pengunjung cukup ramai pada pagi hari. Sangat disayangkan, pasar yang sudah permanen dan sangat bagus banyak yang tidak buka. Sementara itu banyak kios yang tidak buka, akibatnya ada yang rusak tidak terurus Nampak seperti Gambar 1 dan Gambar 2. Namun juga masih ada yang berjualan yaitu penjual sepatu dan baju, seperti pada Gambar 3 dan Gambar 4.

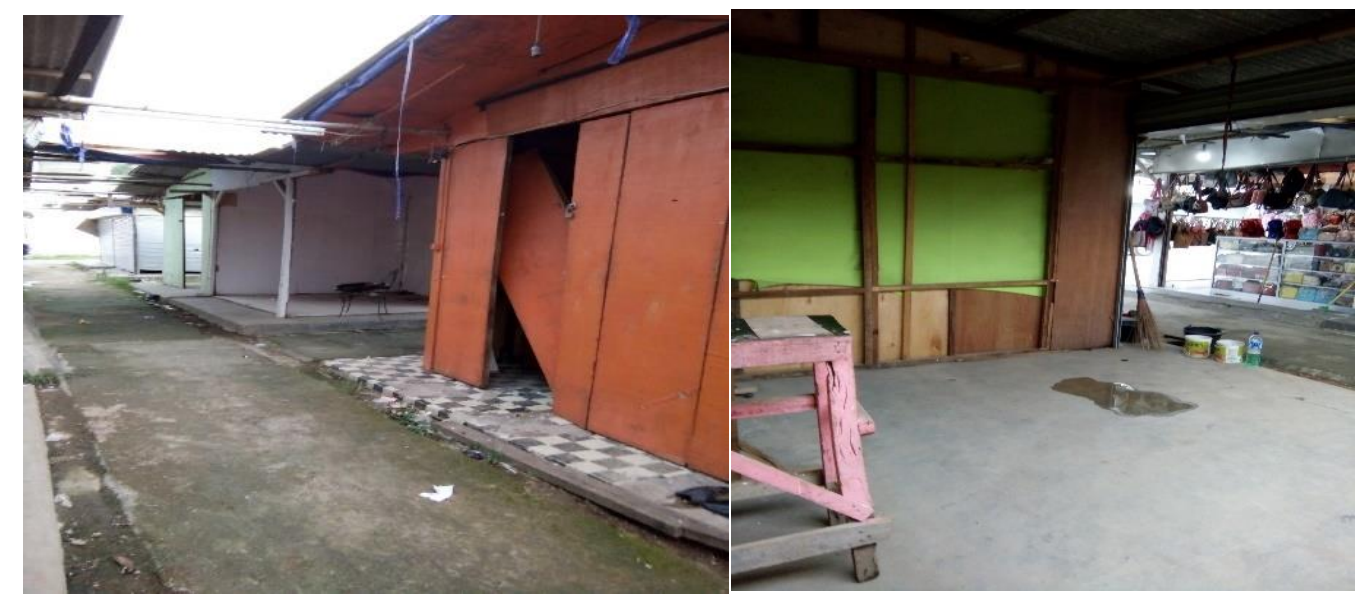

Gambar 1. Kondisi kios di pasar kunciran indah yang rusak, akibat tidak dioperasikan

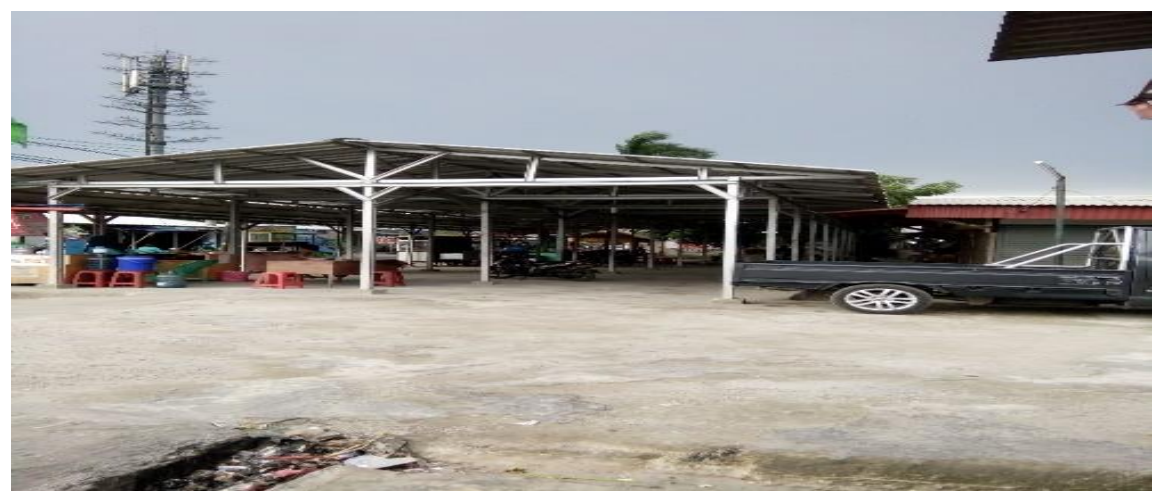

Gambar 2. Suasana pasar kunciran sepi pengunjung. 


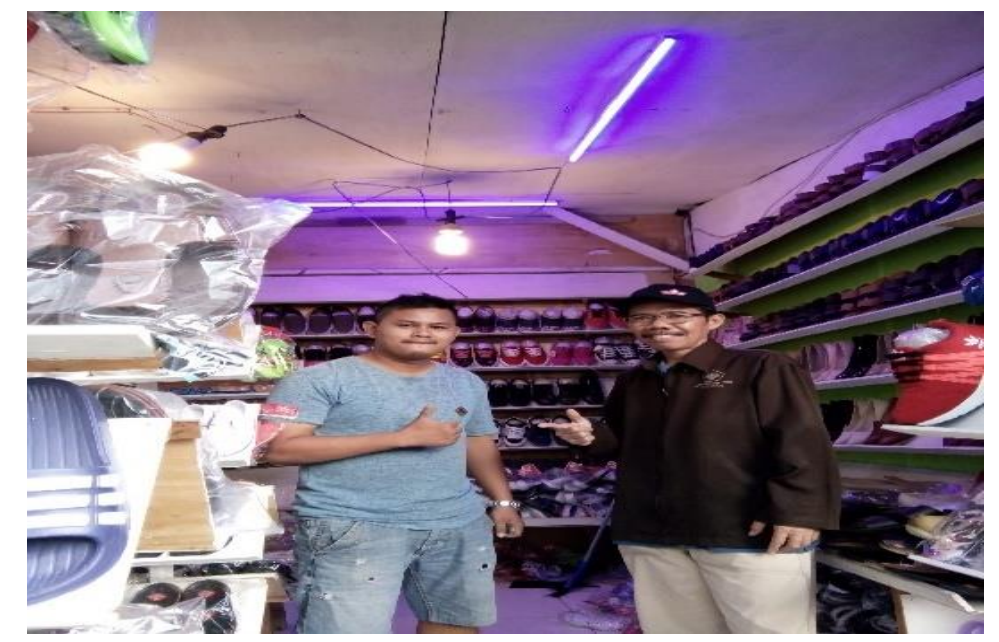

Gambar 3. Salah satu pemilik kios yg berjualan sepatu

Dengan melihat kondisi pasar kunciran ini, banyak pemilik kios yang tidak produktif. Sementara yang lain ingin produktif menjadi tidak termotivasi. Untuk itu masalah mitra dapat dilihat dari aspek manajemen adalah kurang motivasi untuk membuka usaha di pasar kunciran. Menurut Edwin B. Flippo (2009:34), Motivasi merupakan suatu keahlian dalam mengarahkan seorang pegawai dan sebuah organisasi agar dapat bekerja supaya berhasil, hingga para pegawai dan tujuan dari organisasi tersebut tercapai.

Menurut Hamalik (1992:173), Motivasi merupakan perubahan energi dalam diri atau pribadi seseorang yang ditandai dengan timbulnya perasaan dan reaksi untuk mencapai tujuan. Samsudin (2005) memberikan pengertian motivasi sebagai proses mempengaruhi atau mendorong dari luar terhadap seseorang atau kelompok kerja agar mereka mau melaksanakan sesuatu yang telah ditetapkan. Motivasi juga dapat diartikan sebagai dorongan (driving force) dimaksudkan sebagai desakan yang alami untuk memuaskan dan memperahankan kehidupan. Motivasi adalah suatu dorongan kehendak yang menyebabkan seseorang melakukan suatu perbuatan untuk mencapai tujuan tertentu. Motivasi berasal dari kata motif yang berarti "dorongan" atau rangsangan atau "daya penggerak" yang ada dalam diri seseorang. Menurut Malayu (2005:143), Motivasi berasal dari kata latin movere yang berarti dorongan atau pemberian daya penggerak yang menciptakan kegairahan kerja seseorang agar mereka mau bekerja sama, bekerja efektif dan terintegrasi dengan segala daya upayanya untuk mencapai kepuasan.. Menurut Menurut Uno (2007) bahwa motivasi dapat diartikan sebagai dorongan internal dan eksternal dalam diri seseorang yang diindikasikan dengan adanya; hasrat dan minat; dorongan dan kebutuhan; harapan dan cita-cita; penghargaan dan penghormatan. Sedangkan menurut Winardi (2007:1), motivasi berasal dari kata motivation yang berarti "menggerakkan". Motivasi merupakan hasil sejumlah proses yang bersifat internal atau eksternal bagi seorang individu, yang menyebabkan timbulnya sikap entutiasme dan persistensi dalam hal melaksanakan kegiatan-kegiatan tertentu. Sementara aspek produksi perlu adanya pendampingan membuat even atau acara yang menarik pemilki dan pengunjung untuk berbelanja di pasar bandeng. Perlu mempertahankan pengunjung yang sudah ada, menarik pengunjung lain untuk berbelanja di pasar Kunciran. Sehingga promosi perlu dilakukan. Sebagai langkah awal Tim akan membantu bapak A.Syukur selaku mitra ketua pasar untuk mendorong pemilik usaha untuk lebih produktif. 


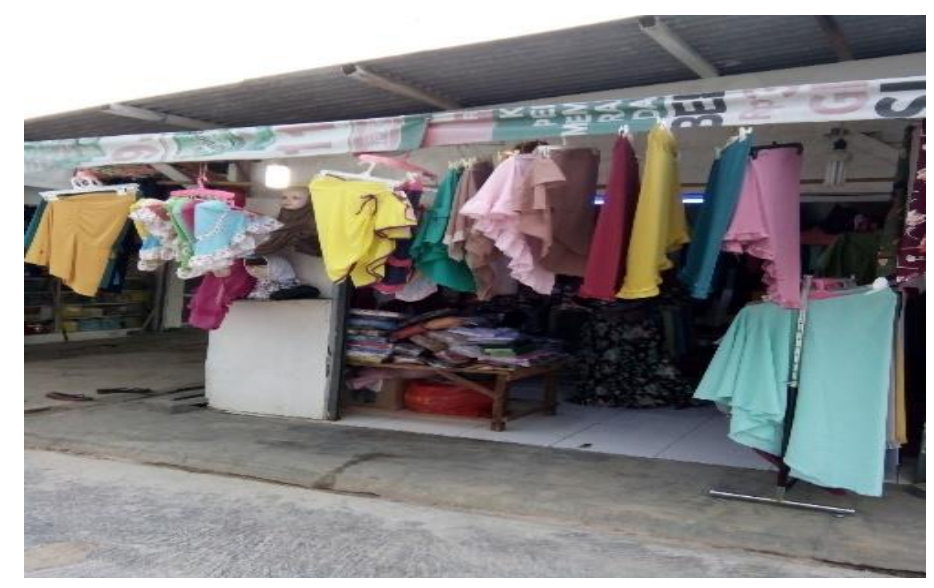

Gambar 4. Kios yang berjualan pakaian

\section{Permasalahan Mitra}

Berdasarkan observasi dan diskusi dengan mitra kelompok pasar yang akan dijadikan mitra yaitu Bapak Abdul Syukur pemilik kios di pasar kunciran di kota Tangerang, permasalahan secara spesifik berkaitan dengan pengelolahan pasar kunciran yang meliputi: 1). Setelah revitalisasi Pasar kunciran kurang ramai pengunjung/konsumen. 2). Peranan para preman masih dominan dilokasi sekitar pasar 3). Kurangnya pengawasan dari pihak pengelolah pasar terhadap pedagang/pemilik kios.

Berdasarkan permasalahan mitra di atas dapat dibedakan antara aspek produksi dan aspek manajemen. Pada aspek produksi yang menunjukkan adanya kelemahan dalam mendorong usaha menjadi lebih unik dari produk pesaing. Pendampingan melakukan pembuatan promosi dan memberikan motivasi. Perlunya pengelolaan pasar secara baik dan keberlanjutan. Berdasarkan analisis situasi di atas, maka, prioritas permasalahan adalah:

1. Bagaimana mendorong atau memotivasi pemilik kios di pasar kunciran untuk menjadi produktif , dengan membuka kios nya atau menyewakannya ke orang lain.

2. Memperkenalkan model promosi dalam meningkatkan penjualan usaha .

3. Bagaimana cara mensosialisasikan metode-metode promosi pada pengelolah pasar agar dapat melakukan penilaian terhadap pemilik kios.

Untuk mengatasi tiga prioritas masalah yang dihadapi oleh kelompok pasar,maka solusi dan luaran yang ditargetkan selesai dari kegiatan pengabdian masyarakat ini adalah:

1. Solusi yang ditawarkan ke mitra berupa memberikan dorongan atau motivasi pada pemilik usaha untuk membuka toko/kiosnya. Spesifikasi yang ditawarkan adalah membuat pertemuan dengan pemilik kios, memberikan himbauan untuk membuka toko maupun menyewakannya ke pengusaha lain, Mendorong untuk saling membantu diantara pemilik kios untuk meramaikan toko, selain itu agar kios kios tidak dijadikan tempat tinggal. Membantu pemillik yang tidak buka, mencarikan penyewa dengan harga sewa yang murah.

2. Melakukan kegiatan promosi. Spesifikasi model adalah: adanya event berkaitan dengan promosi. Spesifikasi yang ditawarkan adalah membuat promosi secra konvensional. Membuat spanduk spanduk, untuk menarik perhatian pengunjung maupun pemilik agar membuka kiosnya. 


\section{METODE PELAKSANAAN PKM}

\section{Solusi Untuk Mengatasi Masalah Mitra}

Berdasarkan hasil diskusi dengan Pemilik kios di pasar kunciran Tangerang, prioritas masalah dihadapi nya adalah sebagai berikut:

a. Aspek manajemen pasar, yang terkait dengan belum adanya dorongan pemilik kios untuk membuka usaha di pasar kunciran. Solusi yang ditawarkan adalah:

1. Memotivasi para memilik kios untuk segera membuka kiosnya.

2.Menawarkan kerjasama dengan pihak lain supaya dapat kemudahan operasionalnya.

b. Aspek produksi terkait dengan masalah pendampingan dalam membuat promosi usaha, yang bertujuan sebagai sarana promosi, sehingga konsumen dapat berkunjung ke lokasi pasar tersebut dan belanja kebutuhannya (Kotler and Keller,2006).

Solusi yang ditawarkan adalah: Pendampingan membuat promosi/atau sarana berupa membuatkan spanduk kegiatan promosi yang menarik konsumen untuk berkunjung di lokasi pasar kunciran.

\section{Model yang Ditawarkan Untuk Mengatasi Masalah Mitra}

\section{a. Memberikan Motivasi Usaha}

Memotivasi pemilik kios untuk mulai membuka kiosnya. Arti motivasi disini adalah prosesproses psikologis yang menyebabkan stimulasi, arahan, dan kegigihan terhadap sebuah kegiatan yang dilakukan secara sukarela yang diarahkan pada suatu tujuan" (Robert Kreitner, 2014). Menurut Uno (2007), motivasi dapat diartikan sebagai dorongan internal dan eksternal dalam diri seseorang yang diindikasikan dengan adanya; hasrat dan minat; dorongan dan kebutuhan; harapan dan cita-cita; penghargaan dan penghormatan.

"Memberi dorongan" artinya memberi semangat kepada orang, memberi harapan dalam kemajuan mereka sendiri, memberitahukan bahwa jalan mereka benar dan dorongan itu akan membantu kalau orang pekerja (pemilik kios) memperlihatkan hal-hal berikut : Kelambanan; Ketakutan (pada waktu ada penjual/pedagang baru); Rasa tidak pasti (mengenai pengakuan dari pemilik kios/penjual); Kelemahan (tidak punya kemampuan untuk selesaikan masalah) dan Tekanan (dari pihak lain). ( Robin P.Stephen dan Coulter, 2005)

Berkaitan dengan sifat hakiki manusia, menurut Mc Gregor membedakan menjadi 2 (dua) kelompok besar, yaitu Teori X dan Teori Y. Dimana teori X menyatakan bahwa pada dasarnya manusia adalah pemalas, tak bertanggung jawab, selalui harus diawasi dan berkerja hanya untuk mencari uang. Sedangkan teori Y menyatakan bahwa pada dasarnya manusia menyukai kerja keras, bertanggung jawab dan hanya membutuhkan dukungan serta rangsangan. (Suyadi, 2012).

\section{Rencana Kegiatan dan Partisipasi Mitra}

Rencana kegiatan dalam rangka pemecahan masalah Pemilik kios di pasar kunciran Tangerang, seperti pada Tabel 1. Jenis luaran yang dihasilkan berupa publikasi jurnal/seminar nasional.

Tabel 1. Rencana Kegiatan \& Partisipasi Mitra pasar

\begin{tabular}{|c|l|l|}
\hline No. & \multicolumn{1}{|c|}{ Rencana Kegiatan } & \multicolumn{1}{c|}{ Partisipasi Mitra } \\
\hline 1 & $\begin{array}{l}\text { Observasi awal dengan kelompok pemilik } \\
\text { kios di pasar kunciran, Tangerang }\end{array}$ & $\begin{array}{l}\text { Mitra responsif/mendukung } \\
\text { mendengar rencana ini. }\end{array}$ \\
\hline 2 & $\begin{array}{l}\text { Membuat FDG tentang motivasi dan promosi } \\
\text { yang diperlukan mitra }\end{array}$ & $\begin{array}{l}\text { Tim berdiskusi dengan mitra } \\
\text { tentang pembuatan promosi }\end{array}$ \\
\hline 3 & $\begin{array}{l}\text { Membuat panduan model promosi pemilik } \\
\text { kios dengan mengkaji aspek manajemen dan } \\
\text { produksi sesuai hasil masukan mitra. }\end{array}$ & $\begin{array}{l}\text { Tim mengkaji aspek } \\
\text { manajemen yang terkait dengan } \\
\text { hasil FGD dengan mitra }\end{array}$ \\
\hline
\end{tabular}




\begin{tabular}{|c|l|l|}
\hline 4 & $\begin{array}{l}\text { Mensosialisasikan motivasi usaha dan } \\
\text { manajemen }\end{array}$ & $\begin{array}{l}\text { Mitra mendengarkan dan } \\
\text { berdiskusi tentang memotivasi } \\
\text { pada pemilik kios di pasar }\end{array}$ \\
\hline 5 & Seminar hasil akhir & $\begin{array}{l}\text { Tim seminar hasil akhir call } \\
\text { paper nasional }\end{array}$ \\
\hline 6 & Pembuatan laporan dan Publikasi & $\begin{array}{l}\text { Tim membuat laporan dan dan } \\
\text { mempublikasikannya ke jurnal } \\
\text { Nasional }\end{array}$ \\
\hline
\end{tabular}

\section{HASIL DAN PEMBAHASAN}

Pasar-pasar tradisional yang berubah menjadi pasar modern yang pasti nyaman dan bersih bagi pengunjungnya. Khusunya pasar yang satu ini yaitu Pasar Kunciran lokasi di Jl. KH. Hasyim ashari, sudimara, pinang, Kota Tangerang. Pasar yang dulunya merupakan pasar tradisional yang sudah ada sejak tahun 2010 bahkan sebelum wilayah disekitar pasar berkembang seperti sekarang ini. Pasar dengan luas kurang lebih 1500 meter persegi ini menjadi pasar kunciran jaya yang menyediakan berbagai macam kebutuhan harian didalamnya. Di jual diperuntukan untuk produk basah seperti sayur-mayur, ikan, daging, dll. Di lokasi ini terdapat sekitar 100 kios dengan ukuran yang berbeda. Pasar Kunciran indah merupakan pilot project dari pembangunan 5 pasar tradisional (pasar lingkungan) yang ada di Kota Tangerang. Jika pembangunan pasar ini sukses, tentunya akan dilakukan pada pasar lainnya. "Kerjasama ini akan dijalin selama lima tahun ke depan. Namun demikian melalui observasi ke pasar kunciran, banyaknya unit kios yang dibangun tidak banyak yang buka, bahkan masih banyak kios yang kosong. Banyak pemilik kios yang tidak membuka tokonya, bahkan tidak ada usaha dari pengelola pasar yang dalam hal ini ditangani pihak swasta tidak ada upaya melakukan event atau promosi yang dapat menarik pemilik untuk membuka usaha. Pasar Lingkungan (Pasling) yang dibangun Perusahaan Daerah Pasar (PD Pasar) Kota Tangerang merupakan wujud kepedulian PD Pasar, terhadap keberadaan pasar agar dekat dengan masyarakat. Hal ini dibuktikan dengan dibangunnya 4 dari 5 Pasling yang sudah berjalan, antara lain Periuk Jaya, Manis Jaya, Jurumudi, Kunciran Indah, dan untuk Larangan Utara dalam tahap finishing.

\section{Model Sosialisasi}

Melalui output pertama yang menghasilkan ringkasan yang dalam bentuk PPT tersebut perlu disosialisasikan pada pemilik usaha, dalam bentuk kegiatan ceramah, terlihat pemilik usaha ini tampak merespon program ini karena mereka dapat menjadi memilki pengetahuan untuk bekal menjalankan usahanya, terutama dalam meningkatkan motivasi usaha dan karyawan. Kegiatan sosialisasi terdapat pada Gambar 5.

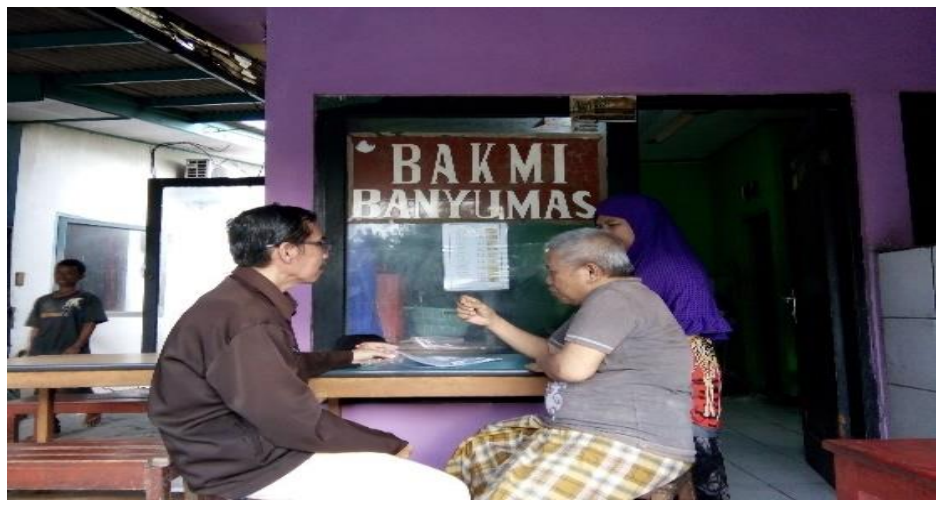

Gambar 5. Wawancara dengan pemilik kios di pasar kunciran indah. 


\section{KESIMPULAN}

Berdasarkan kegiatan PKM yang sudah dilaksanakan dapat disimpulkan sebagai berikut.

Terealisasinya penyusunan materi motivasi usaha; Pelaksanaan sosialisasi kepada mitra usaha tentang Materi promosi berjalan dengan baik.; Pelaksanaan pembuatan media media promosi seperti spanduk; Terealisasinya spanduk spanduk dan lainnya yang dipajang sedemikian rupa sehingga menarik perhatian konsumen yang lalu lalang di depan tempat usaha.

Dengan melihat kondisi pemilik usaha dalam menjalankan usaha, terutama dalam mengkomunikasikan usaha pada konsumen.

\section{Ucapan Terima Kasih (Acknowledgement)}

Pada kesempatan ini kami ingin mengucapkan banyak terima kasih kepada semua pihak yang telah mendukung keberhasilan kegiatan PKM ini, terutama kepada Direkrur PPM beserta Staf Universitas Tarumanagara yang telah membiayai kegiatan ini, juga terima kasih kepada Dekan FE Untar dan Wadek serta kepada Bapak/Ibu pemilik kios di Pasar Kunciran atas kesediaannya menjadi mitra pada kegiatan PKM ini.

\section{REFERENSI}

Edwin B. Flippo, (2009), Manajemen Personalia, Jilid I, Erlangga Jakarta.

Hasibuan, Malayu. (2013). Manajemen Sumber Daya Manusia. Edisi Revisi. Cetakan keenam belas.: PT Bumi Aksara. Jakarta.

-----------------.( 2006). Organisasi dan Motivasi: Dasar Peningkatan Produktivitas. Jakarta: Bumi Aksara.

Hamalik, Oemar. (2013). Kurikulum dan Pembelajaran. Jakarta: Bumi Aksara

Uno. Hamzah B. (2013). Teori Motivasi dan Pengukurannya. Jakarta: Bumi Aksara.

Robert ,Kreitner, dan Angelo Kinicki. (2014). Perilaku Organisasi. Edisi 9. Buku 1. Jakarta: Salemba Empat

Kotler, Philip and Keller, Kevin Lane (2006). Marketing management. Upper Saddle River, New Jersey: Pearson Education.

Robin. P. Stephen., and Coulter. M. (2005). Management., Eight edition, Pearson Prentice Hall, USA.

Samsudin. (2005). Manajemen Sumber Daya Manusia. Bandung Pustaka Setia.

Suyadi. (2012). Penelitian Tindakan Kelas dan Penelitian Tindakan Sekolah. Yogyakarta: Andi.

Winardi. (2007). Motivasi dan Pemotivasian dalam Manajemen. Jakarta : Raja Grafindo Persada. 